\title{
CYP7A1 wt Allele
}

National Cancer Institute

\section{Source}

National Cancer Institute. CYP7A1 wt Allele. NCI Thesaurus. Code C52366.

Human CYP7A1 wild-type allele is located within 8q11-q12 and is approximately $10 \mathrm{~kb}$ in length. This allele, which encodes cytochrome P450 7A1 protein, plays a role in the hydroxylation of cholesterol to initiate bile acid synthesis. Functional mutations in the CYP7A1 gene that decrease or abolish the enzymatic activity of the cytochrome P450 7A1 protein are associated with elevated levels of low density lipoprotein. 